\title{
Exploration of Stable and Phosphine Ligand Free Heterogeneous Catalyst for Ethylene Hydroformylation
}

\author{
LIU Shu-juan ${ }^{1,2}$, WANG Hong-li ${ }^{1,3}$, YUAN Hang-kong ${ }^{1}$, WANG Xin-zhi ${ }^{1,2}$, SHI Feng ${ }^{1 *}$ \\ (1. State Key Laboratory for Oxo Synthesis and Selective Oxidation, Lanzhou Institute of Chemical Physics, \\ Chinese Academy of Sciences, Lanzhou, 730000, China; \\ 2. University of Chinese Academy of Sciences, No. 19A, Yuquanlu, Beijing 100049, China; \\ 3. Dalian National Laboratory for Clean Energy, Dalian, 116023, China)
}

\begin{abstract}
The development of highly active, stable and phosphine ligand free heterogeneous catalyst for hydroformylation reaction remains an open challenge. Herein, we developed highly active, stable and phosphine ligand free heterogeneous catalyst for ethylene hydroformylation reaction by replacing single strongly coordinating phosphine ligand with multiple weakly coordinating oxygen functional groups on the activated carbon surface. Applying of the typical Rh/C-3 catalyst in hydroformylation of ethylene affords unprecedented turnover frequencies (TOFs) up to $57889 / \mathrm{h}$. Besides, the Rh/C-3 catalyst exhibited substantially improved stability in the hydroformylation of ethylene in a fixed-bed reactor (at least $2500 \mathrm{~h}$ ). For the first time, detailed characterizations revealed that lactone group $\left(-\mathrm{CO}_{2}^{-}\right)$on the surface of activated carbon might play a crucial role to gain this catalyst with remarkable activity and stability, which facilitate the homogeneous dispersion and stability of Rh nanoparticles. This work provides a general guidance for the design of highly active, stable and phosphine ligand free heterogeneous catalysts for hydroformylation of olefins.
\end{abstract}

Key words: hydroformylation; carbonylation; heterogneous catalysis; phosphine free

CLC number: 0643.36 Document code: A

Hydroformylation of olefins is one of the most momentous industrial processes for the synthesis of aldehyde, which provides more than 10 million tons' annual output ${ }^{[1-3]}$. The aldehyde can be extensively served as key intermediates in the preparation of esters, alcohols, carboxylic acids, aliphatic amines, and other fine chemicals ${ }^{[4-5]}$. Among the hydroformylation reactions, ethylene hydroformylation, which can generate propanal and 1-propanol, plays an important role. Nowadays, ligand-modified Rh-based homogeneous catalysts are widely used in industrial processes because of their remarkable activity and selectivity as well as mild reaction conditions ${ }^{[5-6]}$. However, this Rhbased homogeneous process faces the problem of losing catalytic active species, catalyst separation and recov- ery. Moreover, the use of organic ligand makes the operation complicated. Compared with homogeneous catalysts, heterogeneous counterparts can be more facilely separated and recycled. Thus, extensive efforts have been devoted to exploit heterogeneous catalysts by loading Rh nanoparticles onto solid supports. So far, Rh supported on many solid supports, such as $\mathrm{SiO}_{2}^{[7-10]}$, carbon materials ${ }^{[7,11-14]}, \mathrm{TiO}_{2}{ }^{[15]}, \mathrm{Al}_{2} \mathrm{O}_{3}^{[16-17]}, \mathrm{Cu}_{2} \mathrm{O}^{[18]}$, $\mathrm{ZnO}^{[19]}$, zeolite ${ }^{[20-22]}$, and $\mathrm{MOF}^{[23-25]}$, have been investigated for heterogeneous ethylene hydroformylation. Nevertheless, their activities and stability are usually low compared with the corresponding homogeneous catalysts ${ }^{[26]}$. To enhance the activity and stability of the heterogeneous catalyst, a nice method of organic phosphine ligand functionalized support via ligand immobi-

Received date: 2020-05-28; Revised date: 2020-06-20

Foundation: NSFC (21633013 and 21925207), National Key Research and Development Program of China (2017YFA0403103), Strategic Priority Research Program of the Chinese Academy of Sciences (Grant No. XDA21020700), Fujian Innovation Academy, Dalian National Laboratory Cooperation Fund, CAS (DNL201901) and the 'Light of West China' Program.

First author: Shujuan Liu (1992-), famale, candidate for PhD's degree, Email: liushujuan@ licp.cas.cn.

Corresponding author: E-mail: fshi@ licp.cas.cn. 
lization or polymerization was developed and applied for the preparation of heterogeneous hydroformylation catalysts ${ }^{[27-32]}$. However, the use of expensive and air sensitive phosphine ligand limited the potential practical applications. So far, the report of highly efficient and stable heterogeneous catalysts without using phosphine ligand toward hydroformylation is still rare.

In fact, it has been reported that the coordination of O-containingligands onto $\mathrm{Rh}$, such as $\mathrm{Rh}$ ( acac) $(\mathrm{CO})_{2}$, can result in high activity for hydroformylation by homogeneous catalysts ${ }^{[33]}$. Therefore, it should be possible to design an active and stable phosphine lig-

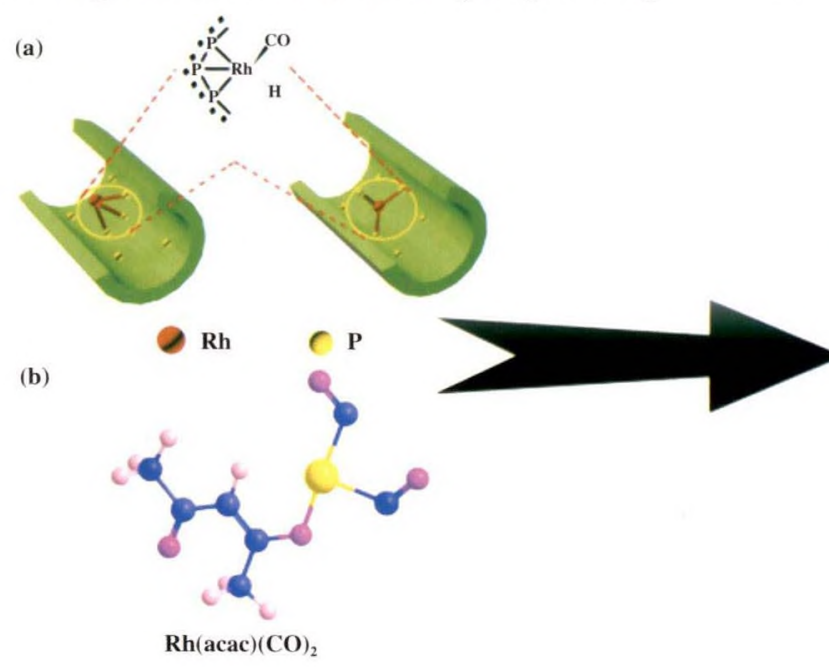

and-free heterogeneous catalyst for ethylene hydroformylation. Among various supports, activated carbons have the advantage of adjustable surface $\mathrm{O}$-containing functional groups. Therefore, we envision that activated carbon with suitable $\mathrm{O}$-coordinating surface functional groups could serve as a good support candidate to prepare highly efficient, stable, and phosphine ligand-free heterogeneous hydroformylation catalysts (Fig. 1). However, although carbon materials as supports have been explored for long time ${ }^{[7,11-12,14]}$, the detailed investigation between the surface structure of carbon materials and catalytic performance is rarely involved. (c)

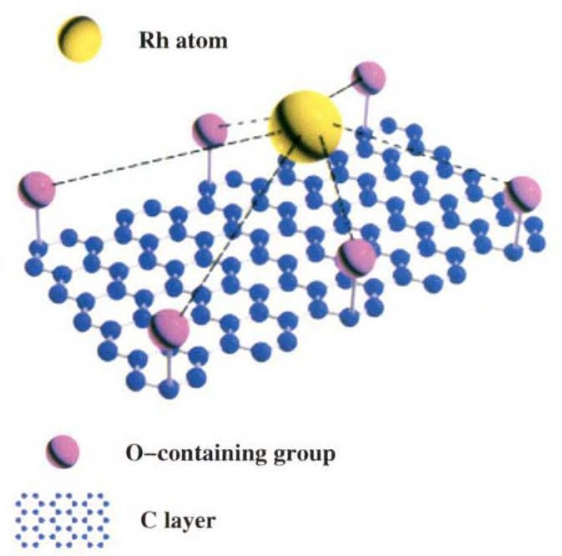

Fig. 1 (a) Rh/POL-PPh $\left(\mathrm{POL}^{-\mathrm{PPh}_{3}}: 3 \mathrm{~V}-\mathrm{PPh}_{3} \text { polymer }\right)^{[34]}$; (b) $\operatorname{Rh}($ acac $)(\mathrm{CO})_{2}{ }^{[33]}$;

(c) $\mathrm{Rh} / \mathrm{C}$ catalyst including air stable $\mathrm{O}$-containing functional groups

Based on our extensively studies on catalyticcarbonylation with $\mathrm{CO}, \mathrm{CO}_{2}$ and other carbonyl resources ${ }^{[35-42]}$, herein, we reported that an activated carbon, which mainly contains lactone and carboxylic acid groups, can be an ideal support for active and stable ethylene hydroformylation catalyst preparation.

\section{Results and discussion}

\subsection{Characterization of catalysts}

First, a series of activated carbons with different $\mathrm{O}$-containing functional groups selected, in which the surface oxygenated groups of the activated carbon supports were explored by Boehm titration analysis ${ }^{[43]}$. Finally, four commercially available activated carbons, i. e., C-1 to C-4, were chosen (Fig. 2(a)). Based on the Boehm titration analysis, the ketone, hydroxyl, lactone and carboxylic groups on C-1, C-3, and C-4 are $0,309,10,70 ; 0,0,624,276$; and 1,231, $201,501,461 \mu \mathrm{mol} / \mathrm{g}$, respectively. No surface oxygenated groups were detectable for C-2.

The supported Rh catalysts were prepared by the precipitation-deposition method and characterized by TEM, XRD, XPS and $\mathrm{N}_{2}$ adsorption-desorption analyses to reveal their structures. First, the morphology and size of $\mathrm{Rh}$ NPs in the $\mathrm{Rh} / \mathrm{C}$ samples were characterized by TEM, and the results are shown in Fig. 2. The STEM images of the Rh/C-1 and Rh/C-2 samples exhibit a large mean particle size of 5.0 and $5.6 \mathrm{~nm}$ with a broad particle size distribution from 2 to $10 \mathrm{~nm}$ due to the aggregation of the NPs (Fig.2(c), (e)). Notably, the STEM images of fresh and used Rh/C-3 show 


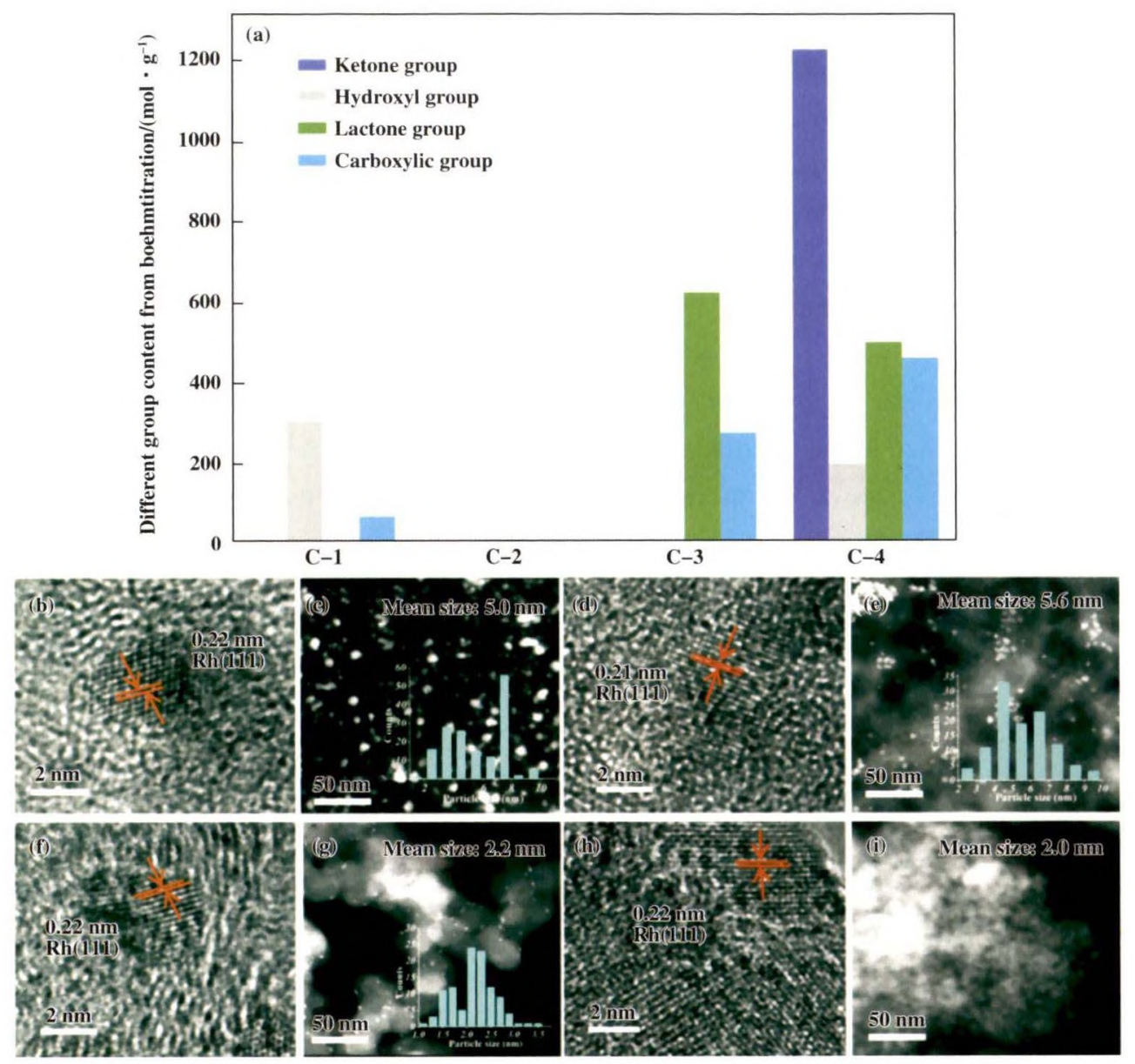

Fig. 2 Structure of the catalysts. Contents of surface oxygenated groups by Boehm titration (a), HR-TEM image of Rh/C-1 (b), STEM of Rh/C-1(c), Rh/C-2 (d), Rh/C-2 (e), Rh/C-3 (f), $\mathrm{Rh} / \mathrm{C}-3(\mathrm{~g}), \mathrm{Rh} / \mathrm{C}-4(\mathrm{~h}), \mathrm{Rh} / \mathrm{C}-4(\mathrm{i})$

Insets are the corresponding particle size distributions

that the Rh NPs are well dispersed on C-3 and exhibit a small mean particle size of 2.2 and $2.1 \mathrm{~nm}$ with a narrow particle size distribution from 1.5 to $3 \mathrm{~nm}$, which might be attributed to the fact that the functional groups on C-3 can be used for anchoring the Rh nanoparticles (Fig.2(g)). The HR-TEM images of Rh particles on fresh and used Rh/C-3 show a lattice spacing of $0.22 \mathrm{~nm}$, which can be indexed to the (111) plane of Rh. Based on above results, we suppose that the lactone group on the surface of C-3 plays a critical role in generating highly dispersed and small Rh NPs.

The XRD patterns of differentRh/C and used Rh/ C-3 samples showed that no peak corresponded to the Rh species can be observed in all the catalysts, which is probably attributed to the small Rh particle size or that the $\mathrm{Rh}$ species were amorphous. Moreover, XPS studies of the catalysts were performed to determine the chemical state of Rh nanoparticles. As shown in Fig.3,

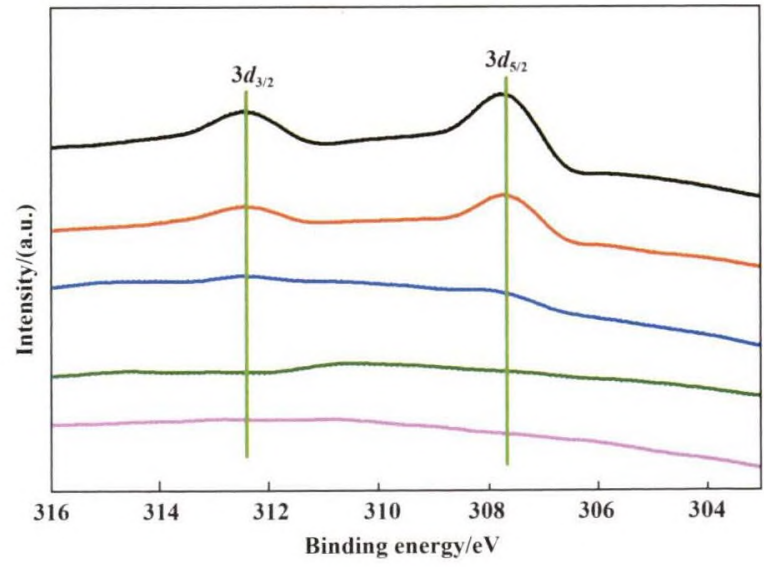

Fig. 3 XPS spectra of the Rh/C catalysts (from top: Rh/C-1, Rh/C-2, Rh/C-3, Rh/C-4 and $\mathrm{Rh} / \mathrm{C}-3$ after being used) 
the XPS spectra of $\mathrm{Rh} 3 d$ in $\mathrm{Rh} / \mathrm{C}-1$ and $\mathrm{Rh} / \mathrm{C}-2$ show two peaks located at binding energies of 307.6 and $312.5 \mathrm{eV}$, corresponding to the metallic $\mathrm{Rh} 3 d_{5 / 2}$ and $\mathrm{Rh} 3 d_{3 / 2}$, respectively. The $\mathrm{Rh} 3 d$ signals of $\mathrm{Rh} / \mathrm{C}-3$, $\mathrm{Rh} / \mathrm{C}-4$, and Rh/C-3 after being used were not observed, which might be attributed to low Rh loadings. The $\mathrm{N}_{2}$ adsorption-desorption tests showed that the BET surface areas of the catalysts of $\mathrm{Rh} / \mathrm{C}-1, \mathrm{Rh} / \mathrm{C}-2, \mathrm{Rh} /$ C-3, and Rh/C-4 were $1423,408,191$ and $1607 \mathrm{~m}^{2} /$ $\mathrm{g}$, in which the BET surface area of $\mathrm{Rh} / \mathrm{C}-3$ is the lowest. Therefore, the better catalytic performance of Rh/ C-3 should not be attributed to the surface area.

\subsection{Catalytic performance of catalysts}

Then, the catalytic performance of the $\mathrm{Rh} / \mathrm{C}$ catalysts was tested (Table 1). Initial hydroformylation experiments were performed at $6 \mathrm{MPa}$ syngas $\left(\mathrm{CO} / \mathrm{H}_{2}=\right.$ $1: 1$ ) with octane as solvent. Clearly, Rh/C-3 exhibits the best catalytic performance. The turnover

Table 1 Screening of the catalyst for ethylene hydroformylation ${ }^{a}$

\begin{tabular}{|c|c|c|c|c|}
\hline Entry & Catalysts $/ 0.0010 \mathrm{mmol}$ & & Yield $/ \%$ & $\mathrm{TOF} /\left(\mathrm{h}^{-1}\right)^{\mathrm{b}}$ \\
\hline 1 & $\mathrm{Rh} / \mathrm{C}-1$ & & 43 & 1897 \\
\hline 2 & $\mathrm{Rh} / \mathrm{C}-2$ & & 47 & 1768 \\
\hline 3 & $\mathrm{Rh} / \mathrm{C}-3$ & & 64 & 3436 \\
\hline 4 & $\mathrm{Rh} / \mathrm{C}-4$ & & 52 & 1168 \\
\hline 5 & $\mathrm{RhCl}_{3} \cdot \mathrm{XH}_{2} \mathrm{O}$ & & $<1$ & - \\
\hline 6 & $\mathrm{RhCl}_{3} \cdot \mathrm{XH}_{2} \mathrm{O}+25 \mathrm{mg}$ & & 3 & 131 \\
\hline 7 & $\mathrm{RhCl}_{3} \cdot \mathrm{XH}_{2} \mathrm{O}+25 \mathrm{mg}$ & -2 & $<1$ & - \\
\hline 8 & $\mathrm{RhCl}_{3} \cdot \mathrm{XH}_{2} \mathrm{O}+25 \mathrm{mg}$ & -3 & 43 & 2004 \\
\hline 9 & $\mathrm{RhCl}_{3} \cdot \mathrm{XH}_{2} \mathrm{O}+25 \mathrm{mg}$ & & $<1$ & - \\
\hline 10 & {$[\mathrm{Rh}(\mathrm{COD}) \mathrm{Cl}]_{2}$} & & 53 & 2491 \\
\hline 11 & $\operatorname{Rh}($ acac $)(\mathrm{CO})_{2}$ & & 76 & 3792 \\
\hline $12^{\mathrm{c}}$ & $\mathrm{Rh} / \mathrm{C}-3$ & & 20 & 57889 \\
\hline
\end{tabular}

a. Reaction conditions: ethylene ( $5 \mathrm{mmol}$ ), cat. $\left(25 \mathrm{mg}, 0.0010 \sim 0.0022 \mathrm{mmol} \mathrm{Rh}\right.$ ), $\mathrm{CO}(3 \mathrm{MPa}), \mathrm{H}_{2}(3 \mathrm{MPa})$, octane $(5.0 \mathrm{~mL}), 100 \pm 2{ }^{\circ} \mathrm{C}, 1 \mathrm{~h}$; The yields were determined by GC-FID with decane as an internal standard;

b. TOF was calculated by moles of aldehyde produced per mole of Rh and per hour;

c. ethylene $(26 \mathrm{mmol}), \mathrm{Rh} / \mathrm{C}-3\left(1 \mathrm{mg}, 4.27 \times 10^{-5} \mathrm{mmol} \mathrm{Rh}\right), 2 \mathrm{~h}$

frequency (TOF) of ethylene reached $3436 \mathrm{~h}^{-1}$ and the desired hydroformylation product, i.e., propanal, was obtained in $64 \%$ yield ( Entry $1-4$, Table 1 ). It should be noted that lower conversions were observed in case of other $\mathrm{Rh} / \mathrm{C}$ ( $\mathrm{Rh} / \mathrm{C}-1, \mathrm{Rh} / \mathrm{C}-2$, and $\mathrm{Rh} /$ C-4) were employed as catalysts. Based on the Rh loading of different $\mathrm{Rh} / \mathrm{C}$ catalysts, the TOF for propanal formation of $\mathrm{Rh} / \mathrm{C}-1, \mathrm{Rh} / \mathrm{C}-2, \mathrm{Rh} / \mathrm{C}-3$ and $\mathrm{Rh} /$ C-4 are $1897,1768,3436$, and $1168 \mathrm{~h}^{-1}$, respectively (Entries 1-4). Thus, the order of catalytic performance of the different $\mathrm{Rh} / \mathrm{C}$ catalysts is $\mathrm{Rh} / \mathrm{C}-3>\mathrm{Rh} /$ $\mathrm{C}-1>\mathrm{Rh} / \mathrm{C}-2>\mathrm{Rh} / \mathrm{C}-4$. It is clear that the catalytic performances of the $\mathrm{Rh} / \mathrm{C}$ are strongly dependent on the structures and quantities of surface oxygenated groups. Combined the Boehm titration analysis and TEM results, we could draw a conclusion that ketone group on the surface of C-3 might play a critical role in highly dispersed and smaller Rh NPs formation, thus resulting in higher catalytic activity of $\mathrm{Rh} / \mathrm{C}-3$ for hydroformylation reaction. The controlled experiment indicated that the $\mathrm{RhCl}_{3} \cdot X_{2} \mathrm{O}$ as catalyst showed a trace conversion of ethylene under the same conditions (Entry 5). In addition, physical mixtures of $\mathrm{RhCl}_{3}$. $\mathrm{XH}_{2} \mathrm{O}$ and activated carbons were explored (Entries 69). Interesting, relatively good yield of $43 \%$ and TOF of $2004 \mathrm{~h}^{-1}$ were obtained with physical mixtures of 
$\mathrm{RhCl}_{3} \cdot \mathrm{XH}_{2} \mathrm{O}$ and $\mathrm{C}-3$ as catalyst, while almost no proponal was observed when C-1, C-2, and C-4 were employed (Entries 6-9). This is a strong evidence to support that C-3 is crucial in the construction of active hydroformylation catalyst. As is well known, $[\mathrm{Rh}$ ( $\mathrm{COD}) \mathrm{Cl}]_{2}$ and $\mathrm{Rh}(\mathrm{CO})(\mathrm{acac})_{2}$ are classical catalyst precursors in hydroformylation of alkenes ${ }^{[44-45]}$. If $[\mathrm{Rh}(\mathrm{COD}) \mathrm{Cl}]_{2}$ was employed, much lower TOF of $2491 \mathrm{~h}^{-1}$ was obtained at the same reaction conditions (Entry 10). Meanwhile, the hydroformylation with Rh ( CO $)(\text { acac })_{2}$ catalyst shows a high TOF of $3792 \mathrm{~h}^{-1}$ (Entry 11). The above results demonstrated the comparable activity of the heterogeneous Rh/C-3. Notably, much higher turnover frequency ( TOF) of $57889 \mathrm{~h}^{-1}$

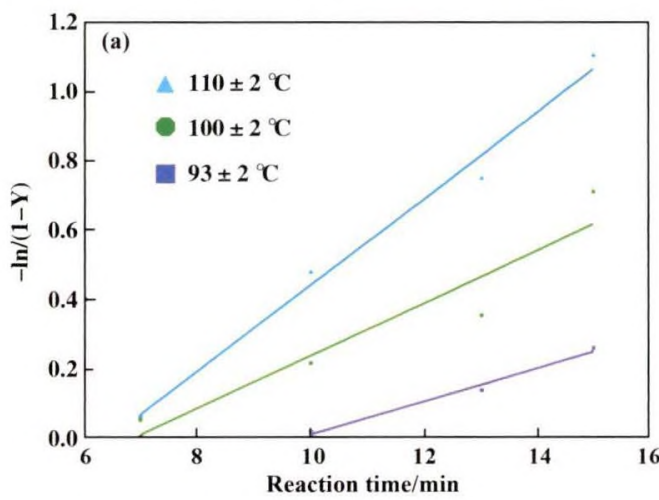

was achieved by decreasing the loadings of $\mathrm{Rh} / \mathrm{C}-3$ catalyst and increasing the quantity of ethylene, which was 5 times of the highest active homogeneous catalyst ( TOF up to $10627 \mathrm{~h}^{-1}$ ) in previous study (Entry $12)^{[46]}$.

Furthermore, the kinetic study on the hydroformylation of ethylene to propanal was conducted over Rh/ C-3 catalyst. The evolution relationship of ethylene conversion with reaction time at different temperatures over Rh/C-3 catalyst was investigated (Fig.4(a)). An Arrhenius plot for ethylene hydroformylation in the temperature interval $93 \sim 110{ }^{\circ} \mathrm{C}$ is obtained, and the apparent activation energy for $n$-propanal formation was calculated to be $67.79 \mathrm{~kJ} \cdot \mathrm{mol}^{-1}$ ( Fig.4(b)).

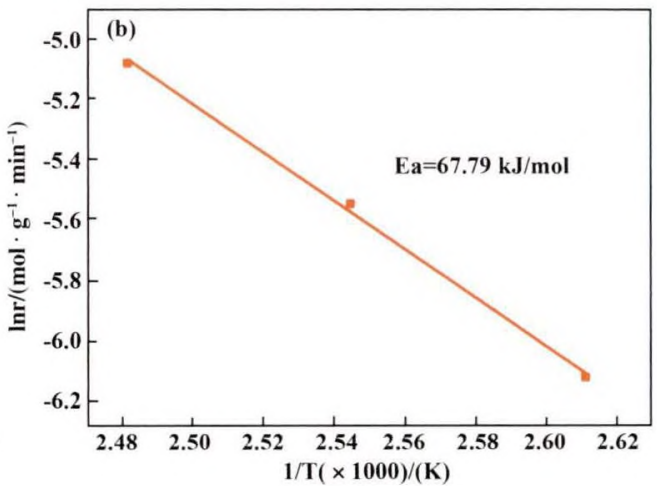

Fig.4 (a). Effect of temperature on rate of propanal synthesis. Ethylene ( $5 \mathrm{mmol}) \mathrm{Rh} / \mathrm{C}-3$ ( $25 \mathrm{mg}, 0.0010 \mathrm{mmol} \mathrm{Rh})$, $\mathrm{CO}(3 \mathrm{MPa}), \mathrm{H}_{2}(3 \mathrm{MPa})$, octane $(5.0 \mathrm{~mL})$; (b). Arrhenius plot for apparent activation energies of the Rh/C-3 catalyst

\subsection{Stability of $\mathrm{Rh} / \mathrm{C}-3$ for the hydroformylation of ethylene}

The stability of the catalyst is very important in heterogeneous catalysis. Therefore, the stability of the $\mathrm{Rh} / \mathrm{C}-3$ catalyst in the hydroformylation of ethylene was investigated with flow system, which would be more valuable in practical process ( Fig.5). To our delight, the propanal yield remained stable for over 2500 $h$, and the selectivity for propanal was $>99.7 \%$, with the generation of trace amounts of ethane, clearly demonstrating that the catalyst was extremely stable. The Rh loadings of the fresh and used Rh/C-3 catalysts over $2500 \mathrm{~h}$ were all in the range of $0.4 \% \sim 0.5 \%$ ( Percent weight). Therefore, the $\mathrm{Rh} / \mathrm{C}-3$ catalyst is stable enough in the fixed-bed system, and hydroformylation with a heterogeneous $\mathrm{Rh}$ catalyst was realized. In previ-

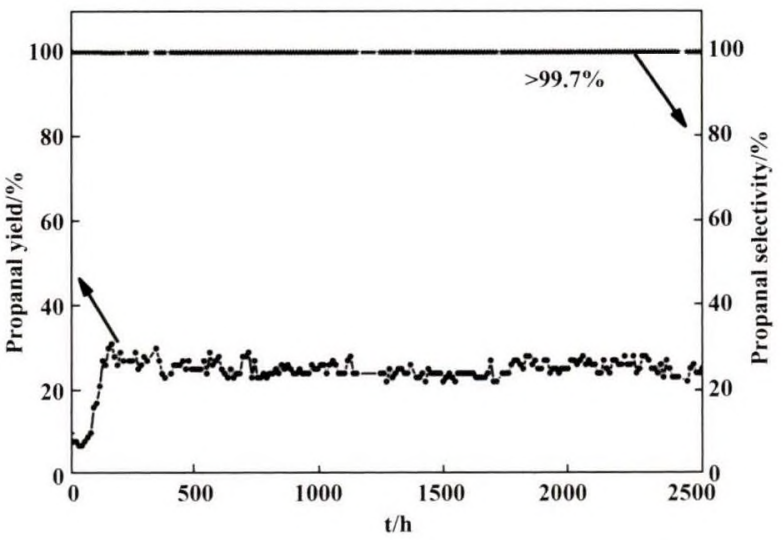

Fig.5 Stability test of the $\mathrm{Rh} / \mathrm{C}-3$ catalyst for ethylene hydroformylation

Reaction conditions: a fixed-bed reactor, $\mathrm{P}=6.0 \mathrm{MPa}$ $\left(\mathrm{C}_{2} \mathrm{H}_{4}: \mathrm{CH}_{4}: \mathrm{CO}: \mathrm{H}_{2}=1: 1: 24: 24\right), \mathrm{T}=95^{\circ} \mathrm{C}$, $2983 \mathrm{~mL} / \mathrm{g}$ Cat $/ \mathrm{h} . \mathrm{CH}_{4}$ was used as the internal standard material for calibration 
ous reports, the lifetime of phosphine ligand-free heterogeneous catalysts was $\sim 70 \mathrm{~h}^{[47]}$, while the number is $\sim 1000 \mathrm{~h}^{[34]}$ with supported phosphine ligand. Thus, our catalyst is the most stable heterogeneous catalyst for ethylene hydroformylation in flow reaction systems so far.

\section{Conclusion}

In conclusion, we have demonstrated a nice heterogeneous ethylenehydroformylation catalyst with both excellent activity and stability based on phosphine ligand free $\mathrm{Rh} / \mathrm{C}-3$ catalyst by replacing the phosphine ligand with air-stable $\mathrm{O}$-containing functional groups on the activated carbon surface. The $\mathrm{Rh} / \mathrm{C}-3$ catalyst showed excellent performance in converting ethylene to propanal with high activity and selectivity. Notably, the Rh/C-3 catalyst exhibited substantially improved stability in the hydroformylation of ethylene in a fixed-bed reactor (at least $2500 \mathrm{~h}$ ). The Boehm titration experiments revealed that the excellent performance of this $\mathrm{Rh} / \mathrm{C}-3$ catalyst could be attributed to that the presence of lactone group $\left(-\mathrm{CO}_{2}-\right)$ on the surface of activated carbon. It not only facilitates the uniform distribution and stabilization of Rh nanoparticles but also boosts the catalytic activity. The results described here may promote the design of active, stable and organic phosphine free heterogeneous catalysts for alkene hydroformylation.

\section{Experiments}

\section{General Information}

XRD measurements were conducted by using a Empyrean instrument equipped with a ceramic X-ray tube and maximum power of $2.2 \mathrm{~kW}$. The XRD patterns were scanned in the 2 Theta range of $10^{\circ} \sim 90^{\circ}$. XPS were obtained using a Escalab 250Xi instrument equipped with monochromatic $\mathrm{Al}$ target and dual anode $\mathrm{Al} / \mathrm{Mg}$ target X-ray sources, including large-area XPS, micro-area XPS and XPS parallel imaging. The electron binding energy was referenced to the $\mathrm{C} 1 s$ peak at $284.8 \mathrm{eV}$. The background pressure in the chamber was less than $10^{-13} \mathrm{MPa}$. TEM was carried out by using a Tecnai G2 F30 S-Twin transmission electron micro- scope operating at $300 \mathrm{kV}$. For TEM investigations, the catalysts were dispersed in ethanol by ultrasonication and deposited on carbon-coated copper grids. The BET surface area measurements were performed on a Quantachrome $\mathrm{IQ}_{2}$ at the temperature of $-196{ }^{\circ} \mathrm{C}$. The pore size distribution wascalculated from the desorption isotherm by using the Barrett, Joyner, and Halenda (BJH) method.

\section{Rh/C Catalysts Preparation}

$500 \mathrm{mg} \mathrm{C}$ were added into a $100 \mathrm{~mL}$ round-bottom flask with $50 \mathrm{~mL}$ distilled water, and dispersed by ultrasound for $30 \mathrm{~min}$. Then $1 \mathrm{~mL} \mathrm{RhCl}_{3} \cdot \mathrm{XH}_{2} \mathrm{O}(5 \mathrm{mg}$ $\mathrm{Rh} / \mathrm{mL}$ ) was added, and further stirred for $4 \mathrm{~h}$ at room temperature. Then the $\mathrm{pH}$ was adjusted by dropwise addition of an aqueous solution of $\mathrm{NaOH}(2 \mathrm{~mol} / \mathrm{L})$, and reduced by dropwise addition of $3 \mathrm{~mL}$ formaldehyde $\left(37 \% \sim 40 \% \mathrm{H}_{2} \mathrm{O}\right)$ in $80{ }^{\circ} \mathrm{C}$ oil bath for $2 \mathrm{~h}$. The precipitates were washed with deionized water, dried in the $80{ }^{\circ} \mathrm{C}$ oven for $12 \mathrm{~h}$. Next, the mixture of the solid and octane were added into a glass tube in $160{ }^{\circ} \mathrm{C}$ for 48 h. Finally, the precipitates were washed with ethyl acetate, and dried in the $80{ }^{\circ} \mathrm{C}$ oven for $12 \mathrm{~h}$.

\section{Typical procedure for hydroformylation of ethylene}

A mixture of ethylene $(5 \mathrm{mmol}), 1 \%$ (Percent weight) $\mathrm{Rh} / \mathrm{C}-3$ ( $25 \mathrm{mg})$, and octane $(5 \mathrm{~mL}$ ) were added into a glass tube which was placed in an $80 \mathrm{~mL}$ autoclave. Then the autoclave was purged and charged with $\mathrm{CO}(3 \mathrm{MPa})$ and $\mathrm{H}_{2}(3 \mathrm{MPa})$. The reaction mixture was stirred at $120{ }^{\circ} \mathrm{C}$ for $3 \mathrm{~h}$. After the reaction finished, the autoclave was cooled to room temperature and the pressure was carefully released. Subsequently, the reaction mixture was diluted with $5 \mathrm{~mL}$ of ethyl acetate. After the solid catalyst was filtered from the solution, the liquid products were analyzed quantitatively by a gas chromatograph (Agilent 7890A) equipped with a capillary column ( HP-5) and a FID detector with decane as an internal standard.

\section{Typical procedures of flow reactions with fix-bed reactor}

The hydroformylation of ethylene was conducted in a continuous flow fixed-bed reactor with an inner diameter of $6 \mathrm{~mm}$ at $95^{\circ} \mathrm{C}, 6 \mathrm{MPa}$ syngas. In catalytic test, $1 \mathrm{~g}$ of catalyst was charged into a stainless steel tubular 
reactor. The effluent was passed through a $500 \mathrm{~mL}$ round-bottom flask filled with $300 \mathrm{~mL}$ of ethyl acetate and the round-bottom flask was cooled to $-20{ }^{\circ} \mathrm{C}$ by a condenser. Propanal was captured by dissolution into the ethyl acetate in the flask. Then, The ethyl acetate solution containing propanal was analyzed quantitatively by a gas chromatograph (Agilent $7890 \mathrm{~A}$ ) with decane as an internal standard, and the gaseous substrate stream was collected by an airbag and monitored by an off-line gas chromatograph from Shimadzu with a FID detector $\left(50 \mathrm{~m} \mathrm{19095P-S25}\right.$ column at $100{ }^{\circ} \mathrm{C}$ ).

\section{The calculated way for plotting Figure 3 from the rate constant $k$ is as follows :}

The corresponding natural logarithm (lnk) values of the rate constants $(\mathrm{k})$ at different temperatures from 93 to $110{ }^{\circ} \mathrm{C}$ for the catalysts were calculated firstly. Then, based on the Arrhenius equation: $\ln \mathrm{k}=\ln \mathrm{A}$ Ea/RT (logarithmic expression), the plots of lnk 1/ $\mathrm{T}$ using linear regression fitting in Origin 8.0 for the $\mathrm{Rh} / \mathrm{C}-3$ catalysts were obtained. The corresponding coefficients of determination of the linear regression fitting for $\mathrm{Rh} / \mathrm{C}-3$ is $\mathrm{R}^{2}=0.998$.

\section{References :}

[1] Piet W N M, Van Leeuwen, Claver C. Rhodium catalyzed hydroformylation $[\mathrm{M}]$. Netherlands: Kluwer Academic Publishers, 2002: 1-13.

[2] Arpe H J. Industrial organic chemistry [M ]. Germany: Wiley-VCH, 2010.

[3] Breit B, Seiche W. Recent advances on chemo-, regioand stereoselective hydroformylation $[\mathrm{J}]$. Synthesis, 2001, 2001 (1): 1-36.

[4] Franke R, Selent D, Borner A. Applied hydroformylation [J]. Chem Rev, 2012, 112(11): 5675-5732.

[5] Wu X F, Fang X, Wu L, et al. Transition-metal-catalyzed carbonylation reactions of olefins and alkynes: A personal account $[\mathrm{J}]$. Accounts Chem Res, 2014, 47 (4) : 1041-1053.

[6] Beller M, Cornils B, Frohning C D, et al. Progress in hydroformylation and carbonylation $[\mathbf{J}] . J$ Mol Catal A: Chem, 1995, 104(1): 17-85.

[7] Sakagami H, Ohta N, Endo S, et al. Location of active sites for 3-pentanone formation during ethene hydroformylation on Rh/active-carbon catalysts [J]. J Catal, 1997, 171(2) : 449-456.
[8] Sandee A J, Reek J N, Kamer P C, et al. A silica-supported, switchable, and recyclable hydroformylation-hydrogenation catalyst [J]. J Am Chem Soc, 2001, 123 (35) : 8468-8476.

[9] Borrmann T, McFarlane A J, Ritter U, et al. Rhodium catalysts build into the structure of a silicate support in the hydroformylation of alkenes [J]. Cent Eur J Chem, 2013, 11(4) : 561-568.

[10] Marchetti M, Paganelli S, Viel E. Hydroformylation of functionalized olefins catalyzed by $\mathrm{SiO}_{2}$-tethered rhodium complexes [J]. J Mol Catal A: Chem, 2004, 222 (1/ 2) : 143-151.

[11] Li B T, Li X H, Asami K, et al. Hydroformylation of 1hexene over rhodium supported on active carbon catalyst [J]. Chem Lett, 2003, 32(4) : 378-379.

[12] Kainulainen T A, Niemela M K, Krause A O I. Hydroformylation of 1-hexene on $\mathrm{Rh} / \mathrm{C}$ and $\mathrm{Co} / \mathrm{SiO}_{2}$ catalysts [J]. J Mol Catal A: Chem, 1997, 122(1): 39-49.

[13] Li X, Zhang Y, Meng M, et al. Silicalite-1 membrane encapsulated $\mathrm{Rh} /$ activated-carbon catalyst for hydroformylation of 1-hexene with high selectivity to normal aldehyde [J]. J Membr Sci, 2010, 347(1) : 220-227.

[14] Ganga V S R, Dabbawala A A, Munusamy K, et al. Rhodium complexes supported on nanoporous activated carbon for selective hydroformylation of olefins $[\mathbf{J}]$. Catal Commun, 2016, 84: 21-24.

[15] Shi Y, Hu X, Chen L, et al. Boron modified $\mathrm{TiO}_{2}$ nanotubes supported Rh-nanoparticle catalysts for highly efficient hydroformylation of styrene $[\mathrm{J}]$. New J Chem, 2017, 41(14) : 6120-6126.

[16] Navidi N, Thybaut J W, Marin G B. Experimental investigation of ethylene hydroformylation to propanal on Rh and Co based catalysts [J]. Appl Catal A-Gen, 2014, 469: 357-366.

[17] Alini S, Bottino A, Capannelli G, et al. Preparation and characterisation of $\mathrm{Rh} / \mathrm{Al}_{2} \mathrm{O}_{3}$ catalysts and their application in the adiponitrile partial hydrogenation and styrene hydroformylation $[\mathrm{J}]$. Appl Catal A-Gen, 2005, 292: 105-112.

[18] Jagtap S A, Bhosale M A, Sasaki T, et al. $\mathrm{Rh} / \mathrm{Cu}_{2} \mathrm{O}$ nanoparticles: Synthesis, characterization and catalytic application as a heterogeneous catalyst in hydroformylation reaction $[\mathrm{J}]$. Polyhedron, 2016, 120: 162-168.

[19] Kontkanen M L, Tuikka M, Kinnunen N, et al. Hydroformylation of 1-hexene over $\mathrm{Rh} /$ nano-oxide catalysts [J]. Catalysts, 2013, 3(1) : 324-337.

[20] Davis M E, Rode E, Taylor D, et al. A comparison of X- 
zeolite-supported and Y-zeolite-supported rhodium as propylene hydroformylation catalysts $[\mathrm{J}]$. J Catal, 1984, 86 (1) : 67-74

[21] Rode E J, Davis M E, Hanson B E. Propylene hydroformylation on rhodium zeolites X and Y I. Catalytic activity $[\mathrm{J}]$. J Catal, 1985, 96(2): 563-573.

[22] Hou C, Zhao G, Ji Y, et al. Hydroformylation of alkenes over rhodium supported on the metal-organic framework ZIF-8 [J]. Nano Res, 2014, 7(9): 1364-1369.

[23] Van Vu T, Kosslick H, Schulz A, et al. Hydroformylation of olefins over rhodium supported metal-organic framework catalysts of different structure $[\mathrm{J}]$. Micropor Mesopor Mater, 2013, 177: 135-142.

[24] Vu T V, Kosslick H, Schulz A, et al. Influence of the textural properties of Rh/MOF-5 on the catalytic properties in the hydroformylation of olefins $[\mathrm{J}]$. Micropor Mesopor Mater, 2012, 154: 100-106.

[25] Van Vu T, Kosslick H, Schulz A, et al. Selective hydroformylation of olefins over the rhodium supported large porous metal-organic framework MIL-101 [J]. Appl Catal A-Gen, 2013, 468: 410-417.

26] Kainulainen T A, Niemelä M K, Krause A O I. Rh/C catalysts in ethene hydroformylation: The effect of different supports and pretreatments $[\mathrm{J}] . J$ Mol Catal A: Chem, 1999, 140(2): 173-184.

[27] Wang T, Wang W, Lyu Y, et al. Porous Rh/BINAP polymers as efficient heterogeneous catalysts for asymmetric hydroformylation of styrene: Enhanced enantioselectivity realized by flexible chiral nanopockets $[\mathrm{J}]$. Chin $J$ Catal, 2017, 38(4): 691-698.

[28] Nowotny M, Maschmeyer T, Johnson B F G, et al. Heterogeneous dinuclear Rhodium(ii) hydroformylation catalysts-performance evaluation and silsesquioxane-based chemical modeling $[\mathrm{J}]$. Angew Chem Int Ed, 2001, 40 (5) : 955-958.

[29] Li C, Sun K, Wang W, et al. Xantphos doped Rh/ $\mathrm{POPs}_{-} \mathrm{PPh}_{3}$ catalyst for highly selective long-chain olefins hydroformylation: Chemical and DFT insights into Rh location and the roles of xantphos and $\mathrm{PPh}_{3}[\mathrm{~J}] . J$ Catal, 2017, 353: 123-132.

[30] Bourque S C, Maltais F, Xiao W J, et al. Hydroformylation reactions with rhodium-complexed dendrimers on silica $[\mathrm{J}]$. J Am Chem Soc, 1999, 121(13): 3035-3038.

[31] Arya P, Panda G, Rao N V, et al. Solid-phase catalysis: A biomimetic approach toward ligands on dendritic arms to explore recyclable hydroformylation reactions [J]. J Am Chem Soc, 2001, 123(12): 2889-2890.
[32] Adint T T, Landis C R. Immobilized bisdiazaphospholane catalysts for asymmetric hydroformylation $[\mathrm{J}] . J A m$ Chem Soc, 2014, 136(22): 7943-7953.

[33] Sakai N, Mano S, Nozaki K, et al. Highly enantioselective hydroformylation of olefins catalyzed by new phosphinephosphite-Rh(I) complexes $[\mathrm{J}] . J$ Am Chem Soc, $1993, \mathbf{1 1 5}(15): 7033-7034$

[34] Jiang M, Yan L, Ding Y J, et al. Ultrastable 3V-PPh polymers supported single Rh sites for fixed-bed hydroformylation of olefins [J]. J Mol Catal A: Chem, 2015, 404/405: $211-217$

[35] Wu Y, Wang T, Wang $\mathrm{H}$, et al. Active catalyst construction for $\mathrm{CO}_{2}$ recycling via catalytic synthesis of $\mathrm{N}$ doped carbon on supported Cu [J]. Nat Commun, 2019, $10(1): 2599$

[36] Liu S, Dai X, Wang H, et al. Organic ligand-free hydroformylation with $\mathrm{Rh}$ particles as catalyst $[\mathrm{J}]$. Chin $J$ Chem, 2019, 38(2): 139-143.

[37] Liu S, Dai X, Wang H, et al. Organic ligand and solvent free oxidative carbonylation of amine over $\mathrm{Pd} / \mathrm{TiO}$, with unprecedented activity [J]. Green Chem, 2019, 21 (15) : 4040-4045.

[38] Dai X, Adomeit S, Rabeah J, et al. Sustainable Co-synthesis of glycolic acid, formamides and formates from 1 , 3-dihydroxyacetone by a $\mathrm{Cu} / \mathrm{Al}_{2} \mathrm{O}_{3}$ catalyst with a single active sites $[\mathrm{J}]$. Angew Chem Int $E d, 2019,58(16)$ : $5251-5255$.

[39] Liu S, Wang H, Dai X, et al. Organic ligand-free carbonylation reactions with unsupported bulk $\mathrm{Pd}$ as catalyst [J]. Green Chem, 2018, 20(15) : 3457-3462.

[40] Cui X, Dai X, Zhang Y, et al. Methylation of amines, nitrobenzenes and aromatic nitriles with carbon dioxide and molecular hydrogen $[\mathrm{J}]$. Chem Sci, 2014, 5 (2): $649-655$

[41] Zhang Y, Dai X, Wang H, et al. Catalytic synthesis of formamides with carbon dioxide and amines $[\mathrm{J}]$. Acta Phys -Chim Sin, 2018, 34(8): 845-857.

[42] Dai X, Wang B, Wang A, et al. Amine formylation with $\mathrm{CO}_{2}$ and $\mathrm{H}_{2}$ catalyzed by heterogeneous $\mathrm{Pd} / \mathrm{PAL}$ catalyst [J]. Chin J Catal, 2019, 40(8): 1141-1146.

[43] Goertzen S L, Theriault K D, Oickle A M, et al. Standardization of the Boehm titration. Part $\mathrm{I} . \mathrm{CO}_{2}$ expulsion and endpoint determination $[\mathrm{J}]$. Carbon, 2010, 48(4): $1252-1261$.

[44] Chaudhari R V, Bhanage B M, Deshpande R M, et al. Enhancement of interfacial catalysis in a biphasic system using catalyst-binding ligands [J]. Nature, 1995, 373 
(6514): 501-503.

[45] Sun Q, Dai Z, Liu X, et al. Highly efficient heterogeneous hydroformylation over Rh-metalated porous organic polymers: Synergistic effect of high ligand concentration and flexible framework $[\mathbf{J}] . J$ Am Chem Soc, 2015, 137 (15) : 5204-5209.

[46] Diao Y, Li J, Wang L, et al. Ethylene hydroformylation in imidazolium-based ionic liquids catalyzed by rhodiumphosphine complexes [J]. Catal Today, 2013, 200: 5462 .

[47] Dossi C, Fusi A, Garlaschelli L, et al. Ethylene hydroformylation with the silica-supported $\mathrm{K}_{2} \mathrm{Rh}_{12}(\mathrm{CO})_{30}$ cluster : Evidence for vapor-phase cluster catalysis $[\mathrm{J}]$. Catal Lett, 1991, 11(3/6): 335-339.

\title{
高稳定性无膦配体乙烯氢甲酰化催化体系研究
}

\author{
柳淑娟 ${ }^{1,2}$, 王红利 ${ }^{1,3}$, 袁航空 ${ }^{1}$, 王新之 ${ }^{1,2}$ ，石 峰 ${ }^{1 *}$ \\ (1. 中国科学院兰州化学物理研究所 羰基合成与选择氧化国家重点实验室, 甘肃兰州 730000 ; \\ 2. 中国科学院大学, 北京, 100049 ; \\ 3. 大连洁净能源国家实验室, 辽宁 大连, 116023)
}

\begin{abstract}
摘要: 高活性、高稳定性的无膦配体多相氢甲酰化催化体系研究是催化化学领域的重要课题. 我们以乙烯氢甲酰 化这一反应为目标, 发展出含有不同含氧官能团的活性炭为载体的负载纳米铑催化材料. 其中, 当以 $\mathrm{Rh} / \mathrm{C}-3$ 这一 材料为催化剂时, 乙烯氢甲酰化反应的转化频率可以达到 $57889 \mathrm{~mol} / \mathrm{mol} / \mathrm{h}$. 该催化剂可以在固定床反应器上稳 定运行 $2500 \mathrm{~h}$ 保持活性稳定. 表征发现, 碳材料表面的内酯基团 (- $\left.\mathrm{CO}_{2}-\right)$ 对催化材料的活性和稳定性具有重要的 作用. 这一研究对高活性、高稳定性的非膦配体多相氢甲酰化催化体系研究具有一定的启示.
\end{abstract}

关键字: 氢甲酰化; 嵈基合成; 多相催化; 非膦配体 


\section{DFT Insight into the Effect of Ni Doping on Hydrocarbons} Synthesis from $\mathrm{CO}_{2}$ Hydrogenation over Fe Catalyst

LIANG Zhi-ming, NIE Xiao-wa, GUO Xin-wen, SONG Chun-shan

J. Mol. Catal. (China) 2020, 34(4): 293 303

It is of great significance to hydrogenate $\mathrm{CO}_{2}$ to produce value-added chemical products. Fe-based catalysts have great potential in converting $\mathrm{CO}_{2}$ and $\mathrm{H}_{2}$ into hydrocarbons, however, the catalytic performance still needs to be further improved. Recently, the bimetallic combination of Fe with a small amount of other active transition metals, such as $\mathrm{Co}, \mathrm{Ni}, \mathrm{Cu}$ or $\mathrm{Pd}$, together with the $\mathrm{K}$ promoter has been revealed to significantly improve $\mathrm{CO}_{2}$ conversion and hydrocarbons production, especially for the synthesis of olefin-rich hydrocarbons. To accomplish similar performance among all the bimetallic catalysts examined, the required amount of $\mathrm{Ni}$ addition is lower than $\mathrm{Co}, \mathrm{Cu}$ and $\mathrm{Pd}$. Therefore, the mechanism of bimetallic synergetic catalysis with

\section{Exploration of Stable and Phosphine Ligand Free Heteroge-} neous Catalyst for Ethylene Hydroformylation

LIU Shu-juan, WANG Hong-li, YUAN Hang-kong, WANG Xin-zhi, SHI Feng

J. Mol. Catal. (China) 2020, 34(4) : 304 312

Hydroformylation of olefins is one of the most momentous industrial processes for the synthesis of aldehyde, which provides more than 10 million tons' annual output. Currently, Rh-based homogeneous catalysts are widely used in industrial processes. However, this Rh-based homogeneous process faces the problems of loss of catalytically active species, catalyst separation and poor recovery. Compared with homogeneous catalysts, heterogeneous counterparts can be more facilely separated and recycled, but the activity and stability are still not good. In order to enhance the activity and stability of the heterogeneous catalysts, organic phosphine ligand-functionalized support was developed, however, the use of expensive and sensitive organic phosphine ligand as well as the complicated processes for homogeneous catalysts immobilized on support limited the further application. Based on our extensively studies on catalytic carbonylation with $\mathrm{CO}, \mathrm{CO}_{2}$ and other carbonyl resources, herein, we developed a highly active, stable and phosphine ligand free

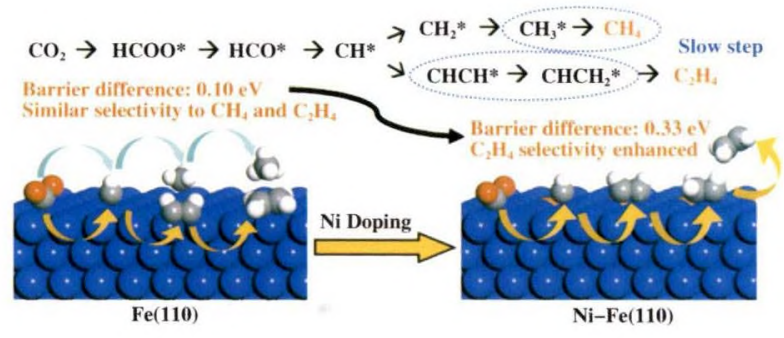

Fe-Ni catalyst for $\mathrm{CO}_{2}$ conversion to hydrocarbons might be different from that of other Fe-M combinations. In this work, density functional theory (DFT) calculations have been performed to investigate the effect of $\mathrm{Ni}$ doping on $\mathrm{C}_{1}$ and $\mathrm{C}_{2}$ hydrocarbons production from $\mathrm{CO}_{2}$ hydrogenation on the $\mathrm{Fe}$ catalyst. The $\mathrm{CH}^{*}$ species is found to be the most favorable monomeric $\mathrm{CH}_{x}{ }^{*}$ species leading to both $\mathrm{CH}_{4}$ and $\mathrm{C}_{2} \mathrm{H}_{4}$ formation on $\mathrm{Fe}(110)$ and $\mathrm{Ni}-\mathrm{Fe}(110)$ surfaces. The calculation results reveal that adding a small amount of $\mathrm{Ni}$ can promote $\mathrm{CH}^{*}$ formation from $\mathrm{CO}_{2}$ hydrogenation, $\mathrm{C}-\mathrm{C}$ coupling of two $\mathrm{CH}^{*}$ species and the further hydrogenation of $\mathrm{C}_{2}$ intermediates to ethylene. 